\title{
EXTERNAL AUDIT AND FISCAL TRANSPARENCY: AN EMPIRICAL ANALYSIS $^{1}$
}

\author{
Huseyin Guclu Cicek \\ Ph.D., Associate Professor, Suleyman Demirel University, Isparta, Turkey. \\ Address: Suleyman Demirel University, Çünür Mahallesi, \\ Süleyman Demirel Cd., 32260 Merkez / Isparta, Turkey. \\ E-mail: huseyincicek@sdu.edu.tr \\ 0000-0003-2883-9468
}

\section{Suleyman Dikmen}

Ph.D., Assistant Professor, Suleyman Demirel University, Isparta, Turkey. E-mail: suleymandikmen@sdu.edu.tr 0000-0002-5434-0532

\begin{abstract}
The aim of this study is to examine the socio-economic, institutional, and political factors affecting external audit, with the use of an international comparison. In addition, the effect of external audit on fiscal transparency was analyzed. Although many empirical studies in the literature handle the factors affecting fiscal transparency, there are only a few empirical studies that focus on the factors affecting external audit and the impact of external audits on fiscal transparency. However, there is not one study dealing with the factors affecting external audit through making use of international comparisons. In this study we attempt to discover the factors affecting external audit and examine, using an international comparison, the impact of external audits on fiscal transparency. The Open Budget Survey published by the International Budget Partnership in 2017 was used to measure external audits. In the study, consisting of 115 countries, the effect of democratization level, government debt level, government balance, gross domestic product (GDP) per capita, legislative budget oversight, the SAI's audit diversity and the effect of a judicial model of the SAI on external audit were investigated. The effect of external audit on fiscal transparency is tested for 115 countries using the Two-Stage Least Squares Method (2SLS). According to the analysis, it is determined that the level of democratization, gross domestic product (GDP) per capita, budget oversight of the legislature, audit diversity of supreme audit institution and judicial model of supreme audit institution have significant and positive effects on external audit. It is also determined that external audit has a significant and positive effect on fiscal transparency.
\end{abstract}

\footnotetext{
1 This study is an enlarged and revised version of the paper presented at the 34th International Public Finance Conference (Antalya/Turkey) held between April 24-27, 2019.
} 
Keywords: external audit; fiscal transparency; Supreme Audit Institution (SAI); Two-Stage Least Squares Method (2SLS).

Jel Codes: H83, M42

Citation: Cicek, H. G. \& Dikmen, S. (2021). External Audit and Fiscal Transparency: An Empirical Analysis. Public Administration Issues, no 5 (Special Issue I, electronic edition), pp. 7-26 (in English). DOI: 10.17323/1999-5431-2021-0-5-7-26

\section{Introduction}

The power to make decisions regarding the collection of public incomes and public expenses belongs to the citizens, thus, the existence of legislative bodies (Yılmaz \& Biçer, 2010). In democratic societies, administrators are expected to account for citizens in terms of collecting public revenues and spending public money. The precondition for accountability is fiscal transparency. Fiscal transparency requires that information on the government's fiscal policy-making process be shared with the public, and reporting on public financial management must be inclusive, clear, reliable, timely, frequent and appropriate (International Monetary Fund (IMF), 2018). The mechanism to provide fiscal transparency and improve accountability is an independent external audit (Köse, 2007). The SAI detects whether the public resources are used in line with the laws, assures the effective management and use of public funds with performance audits, reports the audit outcomes to legislative bodies and announces those to the public, and as a result it contributes to the development of responsibility to accountability and fiscal transparency (Barun, Ekinci \& Temizel, 2007).

Although many empirical studies in the literature deal with the factors affecting fiscal transparency (Alt \& Lassen, 2006b; Benito \& Bastida, 2009; Guillamón, Bastida \& Benito, 2011; Wehner \& de Renzio, 2013; Harrison \& Sayogo, 2014; Cicatiello, De Simone \& Gaeta, 2016; Ríos, Bastida \& Benito, 2016; Arapis \& Reitano, 2017), there are only a few empirical studies that focus on the factors affecting external audit and the impact of external audits on fiscal transparency. Moreover, there is not one study dealing with the factors affecting external audit by making an international comparison. In this study the factors affecting external audit and the impact of external audits on fiscal transparency are examined with the use of an international comparison.

In this context, the aim of this study is to examine the socio-economic, institutional, and political factors affecting external audit through an international comparison. The Open Budget Survey published by the International Budget Partnership in 2017 was used to measure external audit. In the study, consisting of 115 countries, the effect of democratization level, government debt level, government balance, gross domestic product (GDP) per capita, legislative budget oversight, the SAI's audit diversity and the effect of a judicial model of the SAI on external audit were investigated. In addition, the effect of external audit on fiscal transparency was analyzed.

In the study, the detailed literature on external audit and factors affecting external audits are included first. Next, the data set, variables, descriptive statistics, and economic model are mentioned. The study is concluded with the empirical literature and results. 


\section{Theoretical Framework and Literature Review}

A SAI is the national institution in charge of auditing the government's income and expenses. Although they have many duties regulated under the legislation, their main duties are to audit the management of public resources and the quality and reliability of the government's financial data (Stapenhurst \& Titsworth, 2001). SAIs are the institutional indicator of independent auditing in modern societies (Maher, 2004). An audit performed by the SAI is described as an external or supreme audit in the literature (Köse, 2007). An external audit is a form of external evaluation carried out by an independent institution outside the audited institution (Posner \& Shahan, 2014). In considering the audits made, both members of the parliament and citizens ask for accountability by holding government members accountable in political elections, parliamentary talks and public debate areas (Bringselius, 2015). The main element that ensures the transparent execution of state administration is a reliable audit (Feyzioğlu, 1997). In other terms, fiscal transparency is a prerequisite to an efficient external audit (Morgner \& Chêne, 2014). The government needs to be more transparent for a more effective external audit. Fiscal transparency also increases when the SAI carries out an effective external audit. Therefore, there is a bilateral relationship between fiscal transparency and external audit, and this situation is expressed in the literature (Santiso, 2006; 2007b; 2007a) as reverse causality.

The empirical literature on external audit is rather limited. The vast majority of the studies focus on the independence, organizational structure, accountability, and corruption of external audits. There are some studies on the economic and financial effects of external auditing. Talbot and Wiggan (2010) expressed that SAIs are important parts of democratic countries' institutional structure. SAIs contribute to the prevention and blocking of corruption by ensuring good governance, transparency and accountability in public financial management (Kayrak, 2008). SAIs, which provide impartial and independent information to citizens and members of parliament on how the government spends public money, are an indispensable element of the accountability process (Bringselius, 2014). Isaksson and Bigsten (2012) argue that external audit, a mechanism for monitoring the government and transmitting information to voters, is crucial to improving government transparency and accountability. Gonzalez, Lopez and Garcia (2008) also revealed that external audit has an important role in ensuring accountability of the executive body at local and national level.

Independency is a basic feature of audit activity (Gendron, Cooper \& Townley, 2000) and it is meaningless to perform audits without independency (Power, 1997). Clark, Martinis and Krambia-Kapardis (2007) emphasize that external audit has an important role in providing accountability of the public institutions and that the independency of the SAI must be effective in order to increase audit quality. Isaksson and Bigsten (2012) revealed that in the Rwandan example, the capacity limitations have a negative impact on the development of the independency of external audits. Seyfried (2016) examined the factors effective in the election of the SAI chairpersons and revealed that the experience of chairperson candidates and voting rates of the current administration are the main factors. 
The results obtained from the studies revealing the economic and financial impacts of external audit are as follows. Schelker and Eichenberger (2003) reached the outcome that strong audit bodies for Swiss local administrations caused low tax load and public expenses. Eichenberger and Schelker (2006) came up with the outcome that strong audit bodies led to low tax ratios. Torgler (2005) detected that increasing the authorization of SAIs empowered the tax ethics. Torgler and Schaltegger (2006) found that strong supervisory institutions are an important determinant of the level of political debate among the cantons of Switzerland. Olken (2007) revealed that the increase in audit activity in Indonesia reduced the cost of public spending. Ferraz and Finan (2008), on the other hand, found that the publication of audit results before local elections in Indonesia reduced the probability of re-election of the current administrator by $20 \%$. In examining the effects of differences in organizational structures of SAIs on corruption, budget deficit, public expenditures and total factor productivity, Blume and Voigt (2011) found that SAIs in the judicial model are more exposed to corruption than SAIs in the board model, because in countries where the judicial model is adopted, judicial reports do not go to the legislative body and are not made public. This reduces fiscal transparency and increases corruption. Persson and Tabellini (2003) analyzed the impact of constitutional institutions on economic variables and revealed that external auditing led to a reduction in public spending and tax revenues.

Based on the theoretical framework, the basic hypotheses of the study were developed as follows:

Fiscal transparency: Santiso (2006; 2007b; 2007a) found that external audit has a positive relationship with fiscal transparency and that external audit has a significant impact on ensuring fiscal transparency. In addition, Santiso (2007a) concluded that external auditing is not as effective as it should be in ensuring fiscal transparency. Similarly, Schelker and Eichenberger (2010) found that auditing by SAIs increased fiscal transparency by eliminating the principal-proxy problem. Blume \& Voigt (2011), on the other hand, found that the judicial reports are not presented to the legislative body and not disclosed to the public in judicial type SAIs. Morin (2016) observed in the French example that SAI's audit reports created a false sense of transparency and that citizens were given a false sense of trust that the accounts were actually audited.

H1: There is a positive and significant relationship between external audit and fiscal transparency.

Democracy: Democracy and external audit are closely related as a requirement of the historical process. Democratic developments played a leading role in the emergence of audit (Köse, 1999). A democratic management structure is important for the development and effectiveness of an audit (Köse, 2007). The Lima Declaration states that democracy and the rule of law are indispensable elements for truly independent state audits (International Organisation of Supreme Audit Institutions (INTOSAI), 1998). Harrison and Sayogo (2014) found that there is a significant relationship between democracy and public participation in external auditing. A similar conclusion came from Kim (2017) in his study of the South Korean example.

H2: There is a positive and significant relation between external audit and democratization level. 
Economic level: Although developed countries have partially diverged from the traditional audit structure, developing countries have started to increasingly need to structure their control systems as part of their economic development policies and their structural features and functions have converged (Köse, 2007). The SAI oversees the accounts of public institutions to ensure that public money is spent effectively, economically, and efficiently. Auditing of the public sector has a significant impact on growth and per capita income (Blume \& Voigt, 2011). Gustavson (2015) found that there is a positive and significant relationship between external audit and GDP per capita.

H3: There is a positive and significant relationship between external audit and GDP per capita.

Legislative budget oversight: The SAI audits government accounts in line with the mandate of the executive body and reports the results of the audit to the legislature. The legislature oversees government accounts (budget) in line with the report. Santiso (2005) states that increasing the capacity of the SAI and improving its relationship with the legislature positively affects the budget oversight. In addition, Santiso (2006) found that there is a greater correlation between external audit and the centralization of budgetary powers. Ríos et al. (2016) found a positive correlation between SAI's budget audits and the legislative budget oversight.

H4: There is a positive and significant relationship between external auditing and the legislative budget oversight.

Audit versatility of SAI: SAIs usually carry out three types of audit. These are financial auditing, performance auditing, and compliance auditing. In financial auditing, the auditor evaluates the accuracy and impartiality of an entity's financial statements (Stapenhurst \& Titsworth, 2001). In performance auditing, the auditor oversees all activities of the management in terms of efficiency, effectiveness, and frugality (Mutluer, Öner \& Coşkun, 2015). In the compliance audit, the auditor checks whether permits and authorizations are granted for the realization of public income and expenses (Stapenhurst \& Titsworth, 2001). Increasing the diversity of audits performed by SAIs increases the effectiveness of the audits and effective audits support fiscal transparency (Dye \& Stapenhurst, 1998).

H5: There is a positive and significant relationship between external audit and SAI audit diversity.

Countries with judicial model SAI: SAIs are shaped in three different institutional structures: judicial model, office model and board model. In the judicial model, the SAI is independent of the legislative and executive organs and has judicial and administrative authority. Being an integral part of the judicial system, the institution makes decisions regarding the compliance of the government with legislation and ensures that public resources are spent effectively (Stapenhurst \& Titsworth, 2001). Stapenhurst (2014) and Stapenhurst and Titsworth (2001) stated that SAIs have wider powers in countries where the judicial model SAI is available. Blume and Voigt (2011), on the other hand, stated that in countries where judicial model SAIs are present, the audit reports are not sent to the legislative body and the audit is not effective.

H6: There is a positive and significant relationship between external audit and possession of judicial model SAI. 
Government debt: The relationship between financial performance and external audit is demonstrated by two indicators: government debt and government balance. Yalçın $(2017,2018)$ concluded that independent external audit reduces government debt and contributes to the sustainability of government debt. In other words, it has detected a negative relationship between external audits and government debt. Schelker and Eichenberger (2010) revealed that audit reports prepared by the SAI reduce information costs and increase fiscal transparency by eliminating the principal proxy problem. He concluded that the increase in fiscal transparency weakened asymmetric information and reduced government debt.

H7: There is a negative and significant relationship between external audit and government debt.

Government balance: It is important that there is a budgetary deficit or surplus so that the SAI can perform a more effective budget audit. Blume and Voigt (2011) revealed that there is a positive relationship between the external audit performed by the SAI and the budget balance.

H8: There is a positive and significant relationship between external audit and government balance.

\section{Data Set, Variables and Descriptive Statistics}

The main purpose of this study is, within the framework of an international comparison, to identify the socio-economic, institutional and political factors affecting the external audit performed by the SAI. The Open Budget Survey of the International Budget Partnership for 2017 was used to measure external audit and fiscal transparency. Open Budget Survey questions in the external audit (external.audit) variable are presented in Appendix 2. Covering 115 countries, the survey is the world's only independent and comparative measure of fiscal transparency. Since the survey data for 2017 were collected in 2016, the data for the other variables in the study also belong to 2016. The number of samples decreased from 115 to 107 due to insufficient data in other variables. The countries in the sample are located in different geographical regions and have different income levels, political regimes, financial structures and democratic development levels.

In the study, factors affecting external audit are grouped into two categories and independent variables are also classified under this classification. According to this grouping, factors affecting an external audit are (i) socio-economic factors and (ii) political and institutional factors. The socio-economic factors affecting external audits are economic development level $(g d p p c)$, government debt (debt), government balance (government.balance) and democratization level (democra$c y$ ). The institutional and political factors are the budget oversight degree (legislative.oversight), the countries with the judicial model of SAI (judicial.model.SAI) and diversity of inspections (audit. diversity).

Table 1 contains the methods for calculating dependent and independent variables and data sources. Analyses were made using the Stata 13 package program. While creating a data set related to variables, the different methods of calculation of each institution prevented healthy and consistent results from being obtained, and data from reliable and internationally accepted institutions were used. 


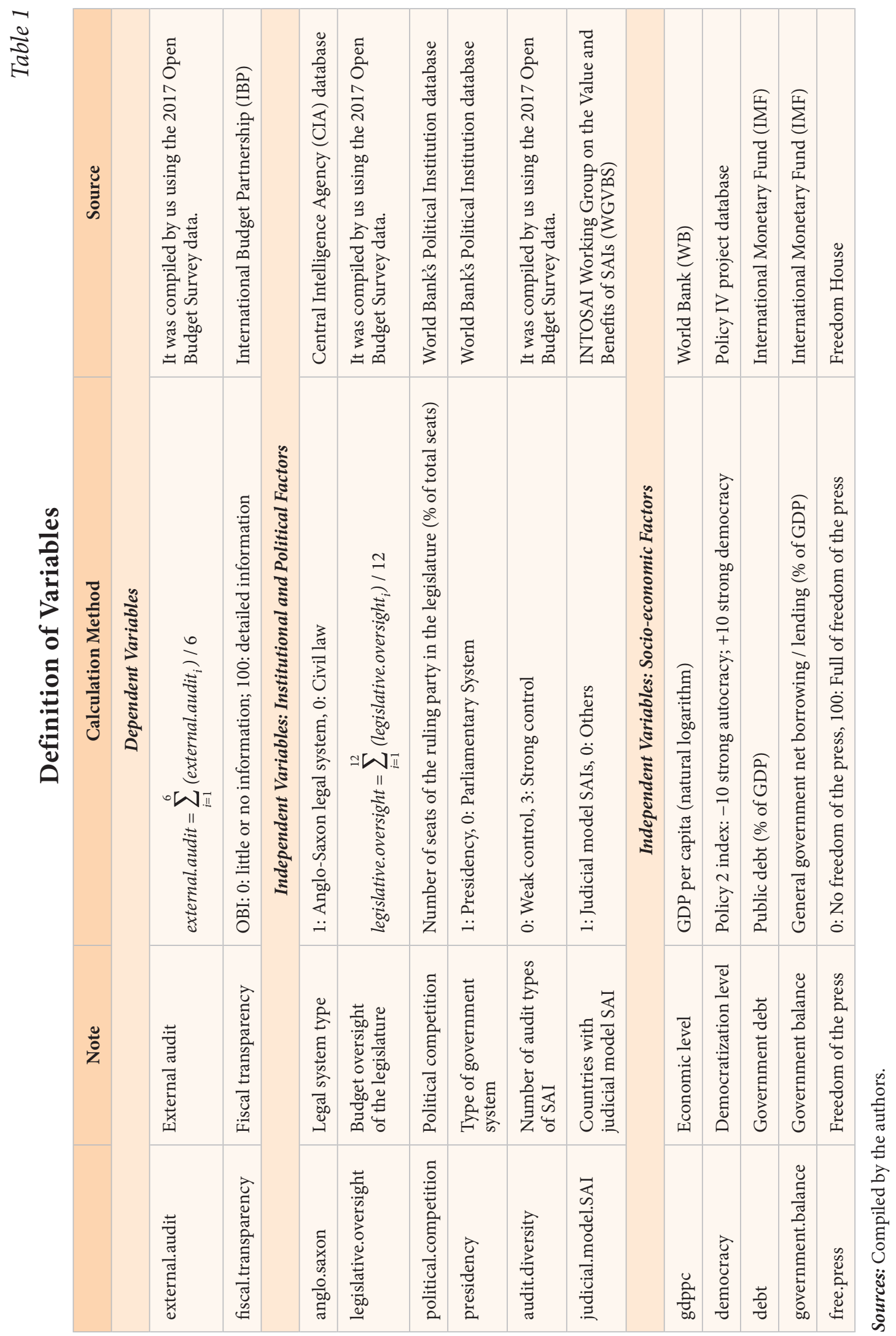


Descriptive statistics regarding the variables used in the model are given in Table 2. The countries with the highest external audit degree of the SAI, created by using the Open Budget Survey, are Australia and South Africa with 100 points. It is 94.5 in Bosnia Herzegovina, Germany, Hungary, Poland, Sweden and the United States. The countries with the lowest external audit score are Equatorial Guinea with 0 points and Qatar with 5.5 points. The country with the highest fiscal transparency is New Zealand with 89.33 out of 100 points. Other countries with a fiscal transparency index score of over 80 points, respectively, South Africa, Sweden, Norway and Georgia. Equatorial Guinea, Lesotho, Qatar and Yemen are the countries with the lowest score -0 fiscal transparency score. These countries do not share their budget information with the public.

Table 2

\section{Descriptive Statistics ${ }^{\star}$}

\begin{tabular}{|c|c|c|c|c|c|c|}
\hline Variable & $\begin{array}{c}\text { Number } \\
\text { of Observations (n) }\end{array}$ & Average & Median & Minimum & Maximum & $\begin{array}{l}\text { Standard } \\
\text { Deviation }\end{array}$ \\
\hline \multicolumn{7}{|c|}{ Dependent Variables } \\
\hline external.audit & 115 & 63,008 & 72,167 & 0 & 100 & 23,486 \\
\hline fiscal.transparency & 115 & 41,854 & 45,266 & 0 & 89,330 & 24,788 \\
\hline \multicolumn{7}{|c|}{ Independent Variables: Institutional and Political Factors } \\
\hline anglo.saxon & 106 & 0,245 & 0 & 0 & 1 & 0,432 \\
\hline presidency & 112 & 0,634 & 1 & 0 & 1 & 0,489 \\
\hline legislative.oversight & 115 & 48,275 & 47,083 & 0 & 91,75 & 20,330 \\
\hline political.competition & 110 & 51,010 & 49,797 & 6,962 & 100 & 22,099 \\
\hline audit.diversity & 115 & 1,965 & 3 & 0 & 3 & 1,249 \\
\hline judicial.model.SAI & 115 & 0,209 & 0 & 0 & 1 & 0,408 \\
\hline \multicolumn{7}{|c|}{ Independent Variables: Socio-economic Factors } \\
\hline gdppc & 112 & 8,277 & 8,272 & 5,655 & 11,168 & 1,376 \\
\hline democracy & 113 & 4,929 & 7 & -10 & 10 & 5,341 \\
\hline debt & 112 & 54,119 & 45,65 & 8 & 239,3 & 31,668 \\
\hline government.balance & 114 & $-4,678$ & $-3,7$ & $-23,1$ & 3,1 & 4,647 \\
\hline free.press & 115 & 47,843 & 48 & 9 & 91 & 20,143 \\
\hline
\end{tabular}

${ }^{*}$ It was created using the Stata 13 package program.

Sources: Compiled according to the calculations of the authors.

From the sample, 26 of the countries have an Anglo-Saxon legal system and 80 have a Civil Law system. In addition, 41 of the countries are governed by a parliamentary system and 71 by a presidential system. The countries where the legislature has the highest budget oversights are Norway, France, Ukraine, South Korea, Indonesia and Germany respectively, while the countries with the lowest 
budget oversight are Qatar and Saudi Arabia with zero points. When the data are evaluated in terms of the political competition representing the number of seats in the legislature of the ruling party, it is seen that the ruling party constitutes the entire legislative body in China, Qatar, Saudi Arabia, Somalia and Yemen. When the number of audits performed by each SAI is analyzed, it is seen that there are no financial audits, compliance audits and performance audits in 28 countries, one in 7 countries, two in 21 countries, and three types in 59 countries. In addition, 24 countries have a judicial model SAI and 91 countries have an Office and Board model SAI.

Considering the data per capita GDP, Burundi is the country with the lowest income and Norway with the highest income. When the countries are evaluated in terms of democratization level, it is seen that 19 countries have 10 full points, which is the most democratic country score, while Qatar and Saudi Arabia, which have -10 points, are the least democratic countries. The country with the highest government debt to GDP ratio is Japan, and the ratio of government debt to GDP is $239.3 \%$. In terms of government balance, 12 countries have a budget surplus and 102 countries have a budget deficit. Norway is the country with the highest budget surplus (3.1\%), while South Sudan is the country with the highest budget deficit (23.1\%). The country with the lowest freedom of press is Equatorial Guinea with 9 points, while the country with the highest freedom is Norway with 91 points.

The correlation relationship between the variables is shown in Appendix 1. The correlation relationship confirms the theoretical expectations between the variables.

\section{Econometric Model}

The theoretical literature shows that there is a problem of endogeneity between external audit and fiscal transparency. Many variables are mutually affected in economic, political and social life. It is a fact that an ordinary least squares (OLS) estimation method has been developed for one-way causality relationships and ignoring the mutual relationship between the variables can cause inconsistent and biased results (Gujarati, 2009). To solve this problem, first of all, the Two-Stage Least Squares (2SLS) estimation method, which takes into account the mutual relationship between the variables, is used. The 2SLS estimation method has been developed for the prediction of over-determined models and it is applied to fully determined models (Tarl, 2012). This method is to estimate the equation to be examined twice with the OLS method (equation 1).

$$
\begin{aligned}
& Y_{t}=\alpha_{0}+\alpha_{1} X_{t}+\alpha_{2} Z_{t}+u_{t 1} \\
& X_{t}=\alpha_{0}+\alpha_{1} Y_{t}+\alpha_{2} K_{t}+u_{t 2}
\end{aligned}
$$

In the first stage, the regression of the internal variables is obtained by finding the regression on all external variables in the model for each internal variable in the structural equation to be estimated (equation 2.): 


$$
\begin{aligned}
& Y_{t}=\Pi_{10}+\Pi_{11} Z_{t}+\Pi_{12} K_{t}+V_{1} \\
& X_{t}=\Pi_{20}+\Pi_{21} Z_{t}+\Pi_{22} K_{t}+V_{2}
\end{aligned}
$$

By applying the OLS method to the obtained equations, the estimated values $\left(\hat{Y}_{t} \hat{X}_{t}\right)$ of the internal variables in the equations are found.

In the second stage (equation 3.), the parameters of the equation are estimated by using the OLS method by substituting the regression values for the internal variables to the right of the structural equation to be estimated (Gujarati, 2009; Tarı, 2012).

$$
\begin{aligned}
& Y_{t}=\alpha_{0}+\alpha_{1} \hat{X}_{t}+\alpha_{2} Z_{t}+e_{t 1} \\
& X_{t}=\alpha_{0}+\alpha_{1} \hat{Y}_{t}+\alpha_{2} K_{t}+e_{t 2}
\end{aligned}
$$

In this context, first of all, the factors affecting the external audit will be analyzed and then the factors affecting the fiscal transparency will be analyzed. However, in the second regression, the factors affecting the external audit will be accepted as a tool variable and the 2SLS estimation method will be used. Accordingly, equation (4.) was used to determine the factors affecting external audit.

external.audit ${ }_{\mathrm{i}}=\alpha+\beta_{1}$ debt $_{1 \mathrm{i}}+\beta_{2}$ democracy $_{2 \mathrm{i}}+\beta_{3} \mathrm{gdppc}_{3 \mathrm{i}}+$

$+\beta_{4}$ legislative.oversight ${ }_{4 \mathrm{i}}+\beta_{5}$ audit.diversity $_{5 \mathrm{i}}+$

$+\beta_{6}$ judicial.model.SAI ${ }_{6 \mathrm{i}}+\beta_{7}$ government.balance $_{7 \mathrm{i}}+\varepsilon_{i}$

In the model, $\mathrm{i}$ index $(\mathrm{i}=1,2, \ldots, 115)$ states countries, $\alpha$ constant term, $\beta_{j i}$ parameters to be estimated, $\varepsilon$ error term.

A second equation (5.) has been added to the model to check the reverse causality relationship due to the endogeneity problem between external audit and fiscal transparency.

fiscal.transparency $=\alpha+\gamma_{1}$ external.audit ${ }_{1 \mathrm{i}}+\gamma_{2}$ free.press $_{2 \mathrm{i}}+$

$+\gamma_{3}$ government.balance $_{3 \mathrm{i}}+\gamma_{4}$ presidency $_{4 \mathrm{i}}+$

$+\gamma_{5}$ political.competition $_{5 \mathrm{i}}+\gamma_{6}$ gdppc $_{6 \mathrm{i}}+\gamma_{7}$ anglo.saxon $_{7 \mathrm{i}}+\varepsilon_{i}$

In the model, $\mathrm{i}$ index $(\mathrm{i}=1,2, \ldots, 115)$ states countries, $\alpha$ constant term, $\gamma_{j i}$ parameters to be estimated, $\varepsilon$ error term.

In the study, factors affecting fiscal transparency were determined by considering the variables used by Alt \& Lassen (2006a) and Ríos et al. (2016). Accordingly, institutional and political factors affecting fiscal transparency are the legal system type (anglo.saxon), political competition (political.competition) and presidency system, while socio-economic factors are economic development level ( $g d p p c)$, democratization level (democracy), press freedom (free.press) and government balance (government.balance). Also included in the model is the external variable (external.audit), which is the internal variable as the explanatory variable of fiscal transparency. 
The OLS method, which is used when determining the factors affecting the external audit, is the method that estimates the average relationship between the dependent and independent variables in the most accurate way if certain assumptions are provided, and there are certain assumptions about the variables and the error term (Tar1, 2012). Variance Inflation Factors [VIF] were calculated to test for multiple linear linkage problems. In order to test for variance problems, the White test and Breusch-Pagan/Cook-Weisberg variance tests were performed. In addition, the Sargan over-determination test was performed for the 2SLS estimation methods in the context of endogeneity testing.

\section{Empirical Results}

Chart 1 shows the relationship between external audit and fiscal transparency. According to the scatter chart, there is a positive relationship between the two variables. The relationship in question supports the literature (Santiso, 2006, 2007a, 2007b).

\section{Chart 1: The Relationship between External Audit and Fiscal Transparency}

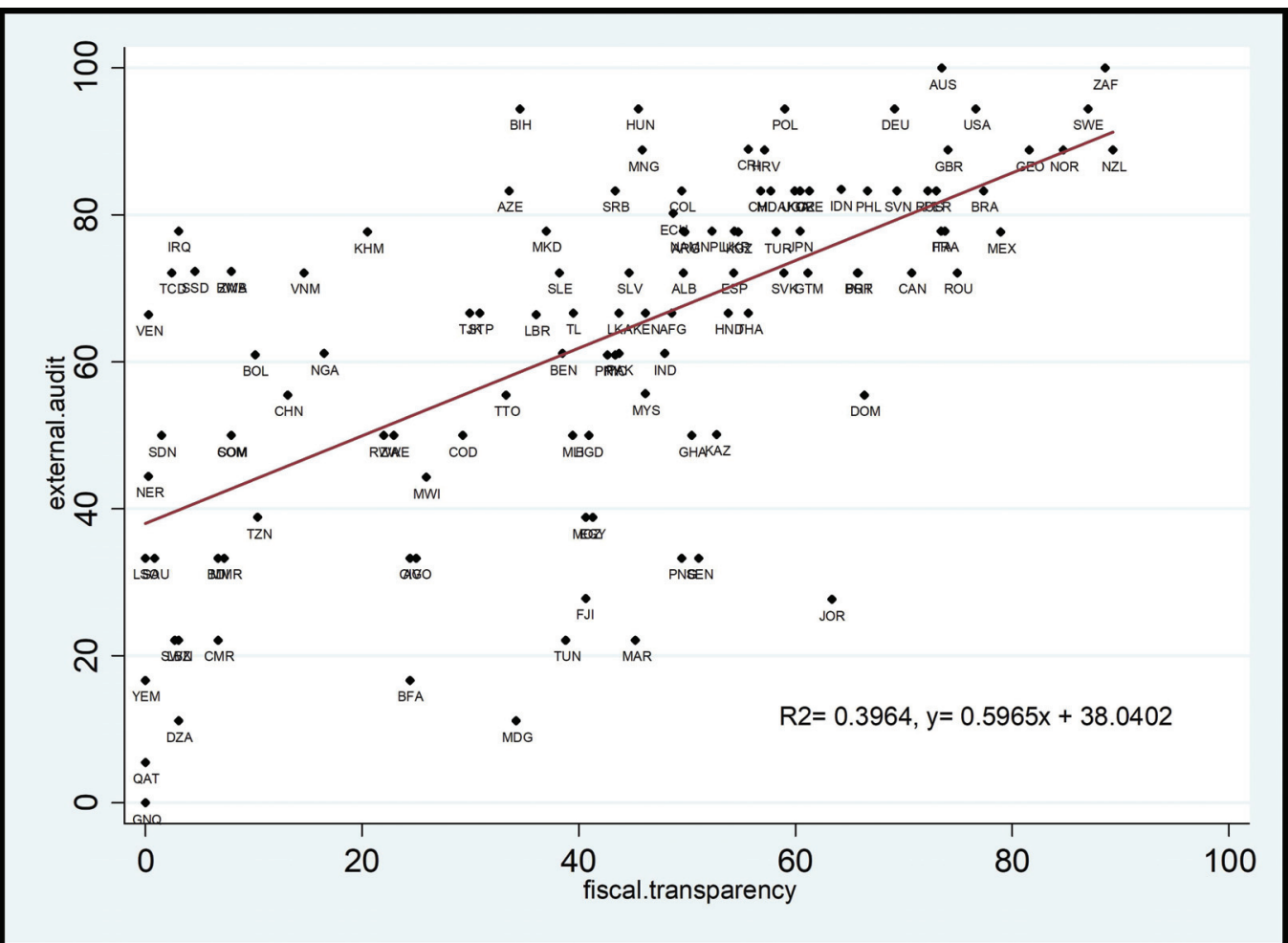

Regression results related to institutional, political and socio-economic factors affecting external audit (Least Squares Estimation Method) are shown in Table 3. The total number of observations in the regression is 107 . Variable names are included in the first column. The second column presents the regression results for 
external audit and the White $\left(\chi^{2}\right)$ variance test. The changing variance problem encountered in regression was eliminated with the robust standard errors method.

Table 3

\section{Factors Affecting External Audit}

\begin{tabular}{|l|c|}
\hline & External Audit (OLS, robust) \\
\hline democracy & $1.01^{\star * *}(0.40)$ \\
\hline gdppc & $2.58^{\star}(1.47)$ \\
\hline legislative.oversight & $0.41^{* * *}(0.95)$ \\
\hline audit.diversity & $3.09^{* *}(1.63)$ \\
\hline judicial.model.SAI & $7.01^{* *}(3.68)$ \\
\hline debt & $-0.05(0.05)$ \\
\hline government.balance & $0.78(0.57)$ \\
\hline Constant Term & $14.12(12.81)$ \\
\hline $\boldsymbol{R}^{2}$ & $\mathbf{0 . 5 7}$ \\
\hline Number of Observations $(\boldsymbol{n})$ & $\mathbf{1 0 7}$ \\
\hline Highest VIF Value & $\mathbf{1 . 5 9}$ \\
\hline White Test $\left(\chi^{2}\right)$ & $\mathbf{8 . 8 1}(\boldsymbol{p}=\mathbf{0 . 0 0 3 0})$ \\
\hline
\end{tabular}

Notes: External Audit (OLS, robust): Ordinary least squares method (OLS) estimation results. Coefficients and standard errors (in parentheses). Significance levels: ${ }^{* *} \mathrm{p}<0.01,{ }^{* *} \mathrm{p}<0.05,{ }^{*} \mathrm{p}<0.1$.

Sources: Compiled according to the calculations of the authors.

It is concluded that democracy (democracy) has a positive and significant effect on external audit. The findings obtained support the literature (Harrison \& Sayogo, 2014; Kim, 2017). As stated by INTOSAI in the Lima Declaration, democracy is a prerequisite for independent state supervision (International Organisation of Supreme Audit Institutions (INTOSAI), 1998).

A positive and significant relationship was found between GDP per capita $(g d p p c)$ and external audit. The findings are in line with the literature (Gustavson, 2015). External control is more effective in economically developed countries.

A positive and significant relationship has been determined between the budget oversight (legislative.oversight) performed by the legislature and external audit. The results obtained are similar to the literature (Santiso, 2005, 2006; Ríos, Bastida \& Benito, 2016). The legislature and SAI work in coordination in the execution of the external audit. The Public Accounts Commission or equivalent institution plays an important role in ensuring coordination between them (van Zyl, Ramkumar \& de Renzio, 2009).

A significant and positive relationship was found between the audit diversity (audit.diversity) performed by the SAI and external audit. Increasing the number of audit types increases the effectiveness of external auditing. This finding is compatible with Dye and Stapenhurst (1998). 
The fact that a country has a judicial model SAI (judicial.model.SAI) has a positive and significant effect on external audit. The findings obtained are in a similar direction to Stapenhurst (2014) and Stapenhurst and Titsworth (2001). In countries where the judicial model SAI is available, the SAI is equipped with broader powers. However, the finding is different with Blume and Voigt (2011). Blume and Voigt (2011) states that the failure of reports to go to the legislature reduces the effectiveness of the audit in countries where the judicial model SAI is available.

There were no significant results between financial performance indicators and external audit. Although there is no significant effect between government debt (debt) and external audit; the coefficient sign is compatible with the literature. Similarly, no meaningful relationship was found between the budget balance (government.balance) and external audit, but the coefficient sign obtained is in accordance with the literature.

The 2SLS estimation method was applied to determine the effect of external audit on fiscal transparency. To test whether there is a problem of endogeneity between external audits and fiscal transparency, the Over-identification (Sargan) Test was conducted. As a result of the test, the effect of external audit on fiscal transparency was analyzed with 2SLS since the problem of endogeneity was encountered. The result of the analysis is shown in Table 4.

Table 4

\section{Factors Affecting Fiscal Transparency}

\begin{tabular}{|l|c|}
\hline & Fiscal Transparency (2SLS) \\
\hline external.audit & $0.76^{\star * *}(0.15)$ \\
\hline gdppc & $2.29(1.68)$ \\
\hline government.balance & $0.83^{\star *}(0.44)$ \\
\hline anglo.saxon & $0.57(4.02)$ \\
\hline political.competition & $-0.07(0.10)$ \\
\hline free.press & $0.27^{\star *}(0.11)$ \\
\hline presidency & $6.88^{\star}(4.03)$ \\
\hline Constant Term & $-34.10^{\star *}(14.34)$ \\
\hline Number of Observations $(\boldsymbol{n})$ & $\mathbf{9 8}$ \\
\hline $\boldsymbol{R}^{2}$ & $\mathbf{0 . 5 2}$ \\
\hline Over-identification $($ Sargan $)$ Test $\chi^{2}$ & $\mathbf{0 . 8 3}(\mathbf{p}=\mathbf{0 . 6 6 1 1})$ \\
\hline
\end{tabular}

Notes: 2SLS (two stage least squares) estimation. Coefficients and standard errors (in parentheses). Significance levels: ${ }^{* * *} \mathrm{p}<0.01,{ }^{* *} \mathrm{p}<0.05,{ }^{*} \mathrm{p}<0.1$.

Sources: Compiled according to the calculations of the authors.

As a result of the analysis, it was found that besides the budget balance (government.balance), press freedom (free.press) and presidency system, one of the determinants of fiscal transparency is external audit (external.audit). The effective 
external audit of the SAI has a positive effect on fiscal transparency. The findings obtained support the literature (Santiso, 2006, 2007b, 2007a; Schelker \& Eichenberger, 2010).

There are many benefits to improving fiscal transparency, an important component of public financial management. If fiscal transparency increases, financial performance increases (Alt \& Lassen, 2006b, 2006a), public foreign borrowing costs decrease (Glennerster \& Shin, 2008), corruption is prevented (Reinikka \& Svensson, 2004), economic stability is maintained and the functioning of the government is streamlined (Heald, 2003). There is also a positive relationship between fiscal transparency and external audit. This was also expressed by many international institutions and organizations (INTOSAI, 1998; 2013; OECD, 2011; International Budget Partnership (IBP), 2017).

\section{Conclusion}

It is an indispensable condition for representative democracies that the legislative bodies, which have the power to decide on the amount and composition of public revenues and expenditures, account for citizens. In order to ensure accountability, fiscal transparency must be provided first. External audit is the main mechanism that ensures fiscal transparency and accountability. Therefore, there is an important relationship between an effective external audit and fiscal transparency and accountability. Based on this relationship, the study aims to analyze the factors affecting external audit and the effect of external audit on fiscal transparency. In line with this purpose, the factors affecting external audits were determined by the OLS estimation method and then the effect of the external audits on fiscal transparency was determined by the 2SLS estimation method. The Open Budget Survey published by the International Budget Partnership in 2017 was used to measure external audit and fiscal transparency.

In the study consisting of 115 countries, factors affecting external audit are grouped as institutional and political factors and socio-economic factors. It is determined that legislative oversight, which is one of the institutional and political factors, has a positive and significant effect on external audit. This finding is important for the quality of external audit. The legislative body and SAI work in coordination during the budget process. The audit reports of the SAI are discussed by the legislative body and decisions are given accordingly by the legislative body. Discussing the reports in the legislative body requires that the SAI work more carefully and meticulously with regard to the reports. It has been determined that the SAI's audit diversity has a positive and significant effect on external audit. This finding shows that the high number of inspection instruments available by an SAI increases the effectiveness of external auditing. In addition, having a judicial type SAI has been found to have a positive and significant effect on external audit. This determination is important in terms of revealing the relationship between the width and effectiveness of the SAI's field of activity.

It is determined that democracy, which is one of the socio-economic factors, has a positive and significant effect on external audit. Increasing the level of democratization is very important for the effectiveness of external audit. 
The public's decision-making position facilitates and speeds up the functioning of the accountability mechanism. In addition to the democratization level, the level of economic development has been found to have a positive and significant effect on external audit. This finding shows that the level of democratic and economic development should be developed for effective external audit.

After determining the factors affecting the external audit, the effect of external audit on fiscal transparency was examined in the study. For this purpose, the 2SLS estimation method is used. It has been determined that external audit has a positive and significant effect on fiscal transparency. SAIs, along with fiscal transparency, are indispensable elements of the accountability mechanism in democratic parliamentary systems. The SAI conducts independent audits on the performance of the executive body. An effective external audit also positively affects fiscal transparency. In addition, apart from external auditing, government balance, freedom of the press and the presidential system have been found to have a positive and significant impact on fiscal transparency.

Since the survey data used are limited, the cross-section data set was used in this study. Since there will be a rich data set over time, examining the relationship between external audit and fiscal transparency using the panel data set will make important contributions to the literature in future studies. In addition, using survey data from other international organizations will provide an opportunity to address the issue from a broad and different perspective.

\section{REFERENCES}

1. Alt, J.E. \& Lassen, D.D. (2006a). Fiscal Transparency, Political Parties, and Debt in OECD Countries. European Economic Review, no 50, pp. 1403-1439.

2. Alt, J.E. \& Lassen, D.D. (2006b). Transparency, Political Polarization, and Political Budget Cycles in OECD Countries. American Journal of Political Science, vol. 50, no 3, pp. 530-550.

3. Arapis, T. \& Reitano, V. (2017). Examining the Evolution of Cross-National Fiscal Transparency. The American Review of Public Administration, vol. 48, no 6, pp. 550-564.

4. Barun, B., Ekinci, M. \& Temizel, Ö. (2007). Kamu Mali Yönetiminin Etkinliğinin Sağlanmasında Dış Denetimin Rolü. In: 22. Türkiye Maliye Sempozyumu. Belek, Antalya, pp. 111-145.

5. Benito, B. \& Bastida, F. (2009). Budget Transparency, Fiscal Performance, and Political Turnout: An International Approach. Public Administration Review, vol. 69, no 3, pp. 403-417.

6. Blume, L. \& Voigt, S. (2011). Does Organizational Design of Supreme Audit Institutions Matter? A Cross-Country Assessment. European Journal of Political Economy, vol. 27, no 2, pp. 215-229.

7. Bringselius, L. (2014). The Dissemination of Results from Supreme Audit Institutions: İndependent Partners with the Media? Financial Accountability \& Management, vol. 30, no 1, pp. 75-94. 
8. Bringselius, L. (2015). In the Absence of a Public Accounts Committee: The Swedish Experience. In: Hoque, Z. (ed.) Making Governments Accountable. London/New York: Routledge, pp. 148-164.

9. Cicatiello, L., De Simone, E. \& Gaeta, G.L. (2016). Political Determinants of fiscal Transparency: A Panel Data Empirical Investigation. MPRA Paper 72609. University Library of Munich, Germany.

10. Clark, C., Martinis, M.De \& Krambia-Kapardis, M. (2007). Audit Quality Attributes of European Union Supreme Audit Institutions. European Business Review, vol. 19, no 1, pp. $40-71$.

11. Dye, K.M. \& Stapenhurst, R. (1998). Pillars of Integrity: The Importance of Supreme Audit Institutions in Curbing Corruption. WBI Working Papers, Report Number: 19684. Washington, DC.

12. Eichenberger, R. \& Schelker, M. (2006). Independent and Competing Agencies: An Effective Way to Control Government. Public Choice, vol. 130, no 1-2, pp. 79-98.

13. Ferraz, C. \& Finan, F. (2008). Exposing Corrupt Politicians: The Effects of Brazil's Publicly Released Audits on Electoral Outcomes. The Quarterly Journal of Economics, vol. 123, no 2, pp. 703-745.

14. Feyzioğlu, B.N. (1997). Sayıștay ve Saydamlık. Sayıştay Dergisi, vol. 8, no 25, pp. 7-9.

15. Gendron, Y., Cooper, D.J. \& Townley, B. (2000). In the Name of Accountability: State Auditing, Independence and New Public Management. Accounting, Auditing \& Accountability Journal, vol. 14, no 3, pp. 278-310.

16. Glennerster, R. \& Shin, Y. (2008). Does Transparency Pay? IMF Staff Papers, vol. 55, no 1, pp. 183-209.

17. Gonzalez, B., Lopez, A. \& Garcia, R. (2008). Supreme Audit Institutions and Their Communication Strategies. International Review of Administrative Sciences, vol. 74, no 3 , pp. 435-461.

18. Guillamón, M.-D., Bastida, F. \& Benito, B. (2011). The Determinants of Local Government's Financial Transparency. Local Government Studies, vol. 37, no 4, pp. 391-406.

19. Gujarati, D.N. (2009). Temel Ekonometri. 6. Basım. Translated by Ü. Şenesen \& G. Günlük Şenesen. İstanbul: Literatür Yayıncılık.

20. Gustavson, M. (2015). Does Good Auditing Generate Quality of Government? Working Paper Series 2015:15. Göteborg, Sweden.

21. Harrison, T.M. \& Sayogo, D.S. (2014). Transparency, Participation, and Accountability Practices in Open Government: A Comparative Study. Government Information Quarterly, vol. 31, no 4, pp. 513-525.

22. Heald, D. (2003). Fiscal Transparency: Concepts, Measurement and UK Practice. Public Administration, vol. 81, no 4, pp. 723-759.

23. International Budget Partnership [IBP] (2017). Open Budget Survey. Available at: https:// www.internationalbudget.org/opening-budgets/open-budget-initiative/open-budget-survey/ (Accessed: December 17, 2017).

24. International Monetary Fund [IMF] (2018). Fiscal Transparency Handbook. Washington, DC. 
25. International Organisation of Supreme Audit Institutions [INTOSAI] (1998). The Lima Declaration. Vienna, Austria.

26. International Organisation of Supreme Audit Institutions [INTOSAI] (2013). ISSAI 100-Fundamental Principles of Public-Sector Auditing. Vienna.

27. Isaksson, A.-S. \& Bigsten, A. (2012). Institution Building with Limited Resources: Establishing a Supreme Audit Institution in Rwanda. World Development, vol. 40, no 9, pp. 1870-1881.

28. Kayrak, M. (2008). Evolving Challenges for Supreme Audit Institutions in Struggling with Corruption. Journal of Financial Crime, vol. 15, no 1, pp. 60-70.

29. Kim, N. (2017). Supreme Audit Institution and Democracy: The Function of the Board of Audit and Inspection (BAI) of Korea for Democratization. In: Im, T. (ed.) The Experience of Democracy and Bureaucracy in South Korea. Bingley, UK: Emerald Publishing, pp. 141-157.

30. Köse, H.Ö. (1999). Denetim ve Demokrasi. Sayıştay Dergisi, no 33, 62-85.

31. Köse, H.Ö. (2007). Dünyada ve Türkiye’de Yüksek Denetim. İkinci Basım. Ankara: 145. Yıl Yayınları.

32. Maher, N. (2004). How Supreme Audit Institution Should Perform and is to be Managed for External Audit. Occasional Papers in Public Administration and Public Policy, pp. 15-34.

33. Morgner, M. \& Chêne, M. (2014). External Audit and Oversight Topic Guide. Transparency International, Vol. I.

34. Morin, D. (2016). Democratic Accountability during Performance Audits under Pressure: A Recipe for Institutional Hypocrisy? Financial Accountability \& Management, vol. 32, no 1, pp. 104-124.

35. Mutluer, M.K., Öner, E. \& Coşkun, A. (2015). Sayıştay Hukuku. İstanbul: İstanbul Bilgi Üniversitesi Yayınları.

36. Olken, B.A. (2007). Monitoring Corruption: Evidence from a Field Experiment in Indonesia. Journal of Political Economy, vol. 115, no 2, pp. 200-249.

37. Organisation for Economic Co-operation and Development [OECD] (2011). Good Practices in Supporting Supreme Audit Institutions. Paris.

38. Persson, T. \& Tabellini, G. (2003). The Economic Effects of Constitutions. London: The MIT Press.

39. Posner, P. L. \& Shahan, A. (2014). Audit Institutions. In: Bovens, M., Goodin, R. E. \& Schillemans, T. (eds.) The Oxford Handbook of Public Accountability. Oxford: Oxford University Press, pp. 488-506.

40. Power, M. (1997). The Audit Society: Rituals of Verification. Oxford: Oxford University Press.

41. Reinikka, R. \& Svensson, J. (2004). The Power of Information: Evidence from a Newspaper Campaign to Reduce Capture. World Bank Policy Research Working Paper. 3239. Washington, DC.

42. Ríos, A.-M., Bastida, F. \& Benito, B. (2016). Budget Transparency and Legislative Budgetary Oversight: An International Approach. American Review of Public Administration, vol. 46, no 5, pp. 546-568.

43. Santiso, C. (2005). Budget Institutions and Fiscal Responsibility: Parliaments and the Political Economy of the Budget Process in Latin America. Washington, D.C.: The World Bank. 
44. Santiso, C. (2006). Improving Fiscal Governance and Curbing Corruption: How Relevant are Autonomous Audit Agencies? International Public Management Review, vol. 7, no 2, pp. 97-108.

45. Santiso, C. (2007a). Auditing for Accountability? Political Economy of Government Auditing and Budget Oversight in Emerging Economies. Johns Hopkins University. Unpublished Doctoral Dissertation. Baltimore, Maryland.

46. Santiso, C. (2007b). Eyes Wide Shut? The Politics of Autonomous Audit Agencies in Emerging Economies.

47. Schelker, M. \& Eichenberger, R. (2003). Starke Rechnungsprüfungskommissionen: Wichtiger als Direkte Demokratie und Föderalismus? Ein erster Blick auf die Daten. Schweizerische Zeitschrift für Volkswirtschaft und Statistik, vol. 139, no 3, pp. 351-373.

48. Schelker, M. \& Eichenberger, R. (2010). Auditors and Fiscal Policy: Empirical Evidence on a Little Big Institution. Journal of Comparative Economics, vol. 38, no 4, pp. 357-380.

49. Seyfried, M. (2016). Setting a Fox to Guard the Henhouse? Determinants in Elections for Presidents of Supreme Audit Institutions: Evidence from German Federal States (19912011). Managerial Auditing Journal, vol. 31, no 4, pp. 492-511.

50. Stapenhurst, R. (2014). Budgetary Oversight in Westminster and Francophone Parliaments Compared - What Can They Learn from Each Another? In: 60th Commonwealth Parliamentary Conference.

51. Stapenhurst, R. \& Titsworth, J. (2001). Features and Functions of Supreme Audit Institutions. PREM Notes; no 59. Washington, DC.

52. Talbot, C. \& Wiggan, J. (2010). The Public Value of the National Audit Office. International Journal of Public Sector Management, vol. 23, no 1, pp. 54-70.

53. Tar1, R. (2012). Ekonometri. 8. Bask1. Kocaeli: Umuttepe Yayınlar1.

54. Torgler, B. (2005). A Knight Without a Sword? The Effects of Audit Courts on Tax Morale. Journal of Institutional and Theoretical Economics, vol. 161, no 4, pp. 735-760.

55. Torgler, B. \& Schaltegger, C.A. (2006). The Determinants of Political Discussion: How Important Are Audit Courts and Local Autonomy?, no 28.

56. Wehner, J. \& de Renzio, P. (2013). Citizens, Legislators, and Executive Disclosure: The Political Determinants of Fiscal Transparency. World Development. Elsevier Ltd, vol. 41, no 1, pp. 96-108.

57. Yalçın, S. (2017). Mali Şeffaflık ile Yüksek Denetim Kurumlarının Bağımsızlı̆̆ı ve Örgütlenme Yapilarının Mali Performans Üzerindeki Etkisi: Bir Panel Veri Analizi. Hacettepe Üniversitesi Sosyal Bilimler Enstitüsü Maliye Anabilim Dalı, Unpublished Doctoral Dissertation. Ankara.

58. Yalçın, S. (2018). The Effects of Supreme Audit Institutions' Independency on Public Debt Sustainability: An Investigation for Turkey. Muhasebe Bilim Dünyası Dergisi, vol. 20, no 2, pp. 375-388.

59. Yılmaz, H. H. \& Biçer, M. (2010). Parlamentonun Bütçe Hakkını Etkin Kullanımının Yeni Bütçe Sistemi Çerçevesinde Değerlendirilmesi. Maliye Dergisi, no 158 (Ocak-Haziran), pp. 201-225.

60. van Zyl, A., Ramkumar, V. \& de Renzio, P. (2009). Responding to the Challenges of Supreme Audit Institutions: Can Legislatures and Civil Society Help? Bergen. 


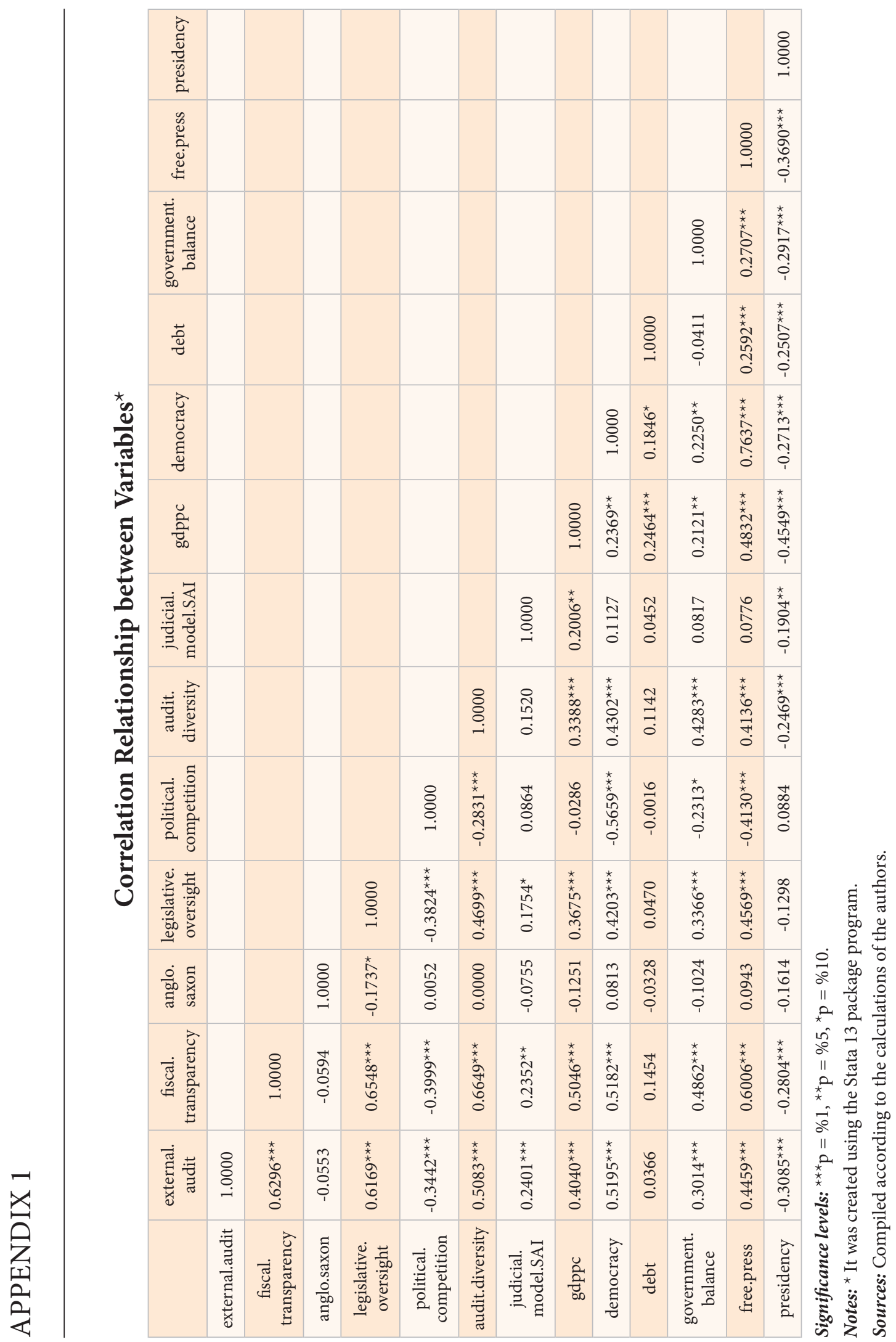




\section{APPENDIX 2}

\section{Open Budget Survey Questions in the external.audit Variable}

Open Budget Survey questions included in the external.audit variable

1. (Question 119) Was the process of appointing (or re-appointing) the current head of the SAI carried out in a way that ensures his or her independence?

2. (Question 120) Must a branch of government other than the executive (such as the legislature or the judiciary) give final consent before the head of the Supreme Audit Institution (SAI) can be removed from office?

3. (Question 121) Who determines the budget of the Supreme Audit Institution (SAI)?

4. (Question 122) Does the Supreme Audit Institution (SAI) have the discretion in law to undertake those audits it may wish to?

5. (Question 123) Are the audit processes of the Supreme Audit Institution (SAI) reviewed by an independent agency?

6. (Question 124) In the past 12 months, how frequently did the head or a senior staff member of the Supreme Audit Institution (SAI) take part and testify in hearings of a committee of the legislature? 